\title{
The Role of Autophagy in Rotenone-Induced Neurotoxicity in Mice
}

\author{
Eman A. Abdel-Razek ${ }^{1}$, Amal A. El-Bakary ${ }^{1}$, Sameera Sh. Hamed ${ }^{1}$, Mohamed Salama ${ }^{1,3}$, \\ Amany Hassan ${ }^{2}$, Sara El-desouky ${ }^{3}$, Adel EL-Mansoury ${ }^{1}$
}

\begin{tabular}{|c|c|}
\hline & ABSTRACT \\
\hline $\begin{array}{l}\text { KEYWORDS } \\
\text { Neurotoxicity, } \\
\text { Rotenone, } \\
\text { Mice, } \\
\text { Autophagy. }\end{array}$ & $\begin{array}{l}\text { Rotenone is widely used insecticide and pesticide. It is an environmental } \\
\text { neurotoxin that induces accumulation of } \alpha \text {-synuclein and deterioration of } \\
\text { dopaminergic neurons in substantia nigra pars compacta (SNpc). Autophagy- } \\
\text { mediated self-digestion of cytoplasmic inclusions may be defensive against } \\
\text { neurodegeneration caused by rotenone toxicity. This study designed to assess the } \\
\text { autophagy role in rotenone-induced neurotoxic effects. Sixteen C57 black } 6 \text { male } \\
\text { mice were divided into rotenone \& control groups, each group contains } 8 \text { mice: the } \\
\text { rotenone group; mice were administrated rotenone ( } 3 \text { mg/kg/day intraperitoneally). } \\
\text { In the control group carboxymethyl cellulose } 0.5 \% \text { a vehicle for rotenone) was given } \\
\text { as 3mL/Kg/day intraperitoneal. Neuro-behavioural locomotor tests, histo- } \\
\text { pathological and immuno-histochemical analysis of the brain dopaminergic neuronal } \\
\text { cells and counting of microtubule Associated Protein Light Chain } 3 \text { (LC3) positive } \\
\text { cells expression were investigated. Results showed that rotenone administration } \\
\text { increases the total distance travelled, numbers of line crossing, average speed, } \\
\text { maximum speed and rotations of the animal's body. However, it significantly } \\
\text { decreases the efficient path and the total mobile and immobile episodes and induced } \\
\text { severe degenerative changes in histo-pathological examination. Also, it decreased } \\
\text { significantly the quantity of LC3 positive cells in the brain sections of exposed mice } \\
\text { i.e. neurodegeneration and inhibition of autophagy in dopaminergic system. From } \\
\text { this study it can be concluded that rotenone can induce neurotoxicity through } \\
\text { inhibition of autophagy. }\end{array}$ \\
\hline
\end{tabular}

\section{Introduction}

Rotenone has been widely used as both herbicide and insecticide. It induces apoptosis of dopaminergic (DA) neuronal cells, augments oxidative stress and neuroinflammatory reaction in the dopaminergic neurons and increases the creation of $\alpha$-synuclein

(l) Forensic Medicine and Clinical Toxicology Department, Mansoura University, Mansoura, Egypt.

${ }^{(2)}$ Pathology Department, Mansoura University, Mansoura, Egypt.

${ }^{(3)}$ Medical Experimental Research Center (MERC), Mansoura University, Mansoura, Egypt. cytoplasmic enclosures in DA system (Blesa et al., 2012; Hoffman et al., 2019).

Autophagy "self- eating" is physiological cellular process via which protein aggregates and impaired organelles go through lysosomemediated auto-digestion and recycling so one can maintain cytoplasmic homeostasis. Autophagy may be dys-regulated in several disorders, as metabolic, infectious and neurodegenerative illnesses as well as cancer (Feng et al., 2014; Netea-Maier et al., 2016).

Because the deregulation of the autophagic pathway is involved in a broad spectrum of human illnesses, autophagy is a 
particularly motivating target for therapeutic intervention (Choi et al., 2013). Light chain 3 (LC3) positive cells expression was used to assess grade of autophagy enhancement as; this protein is recognized on autophagosomes and helps as a broadly used indicator for autophagosomes (Mizushima et al., 2010). Definitely, autophagy stimulation declines the toxic buildup of diverse malformed proteins, along with mutant $\alpha$ - synuclein (causing Parkinson's illness) (Zheng et al., 2010).

Rotenone administration shows oxidative stress via reactive oxygen species (ROS) generation and decreasing reduced glutathione levels. Under normal metabolic procedures ROS are produced in very little degrees which are cleared by using in vivo antioxidant defense structure. However, oxidative stress as a result of rotenone can overwhelm autophagic flux resulting in buildup of protein aggregates $(\mathrm{Hu}$ et al., 2016). The aim of this study is to assess the role of autophagic process in rotenone induced neurotoxic changes.

\section{Material and methods}

\section{Study design:}

This experimental study was accepted by Institutional Research Board (IRB), Faculty of Medicine, Mansoura University (code number: MD/ 17.03.149). This research was performed in the Medical Experimental Research Centre (MERC), Faculty of Medicine, Mansoura University.

Sixteen C57 black 6 male mice, about 25$30 \mathrm{~g}$ weight, were divided into rotenone and control groups, each group contains 8 mice. The rotenone group (Rot); mice were administrated rotenone $(3 \mathrm{mg} / \mathrm{Kg} /$ day intraperitoneally). In the control group (Con) carboxymethyl cellulose $0.5 \%$ (a vehicle for rotenone) was given as $3 \mathrm{~mL} / \mathrm{Kg} /$ day intraperitoneal (Salama et al., 2012). Both were given for 35 days. Mice were kept under suitable laboratory circumstances with a 12- hour light/dark cycle and room temperature 22 $\pm 2^{\circ} \mathrm{C}$.

\section{Methods:}

Study of the neurotoxic consequences of rotenone was undertaken by neuro-behavioural locomotor tests, histo-pathological assessment and immuno-histochemical analysis of the brain dopaminergic neuronal cells and counting of microtubule Associated Protein Light Chain 3 (LC3) positive cells expression. The LC3 positive cells expression was counted to evaluate grade of autophagy enhancement.

\section{1- Neuro-behavioural (locomotor) assessment:}

The locomotor activity of the studied mice was measured at the $35^{\text {th }}$ day of the study by usage of ANY-box tests. Open field test evaluated neurobehavioral function for each mouse by the subsequent parameters: the total travelled distance (in meters), the average speed (meters per second), the maximum speed (meters per second), efficient path, rotations of the animal's body, numbers of line crossing and the total mobile and immobile episodes.

\section{2- Histopathological assessment:}

At the $35^{\text {th }}$ day, under general anesthesia through use of $100 \mathrm{mg} / \mathrm{Kg}$ thiopental (intraperitoneal), animals were perfused through the aorta with $10 \mathrm{mM}$ phosphatebuffered saline (PBS) $(50 \mathrm{~mL})$, after that 150 $\mathrm{mL}$ of $4 \%$ paraformaldehyde was injected for fixation of brain tissues. Subsequently, every brain was rapidly divided and fixed for 48 hours with $10 \%$ paraformaldehyde. The brain sections had been preserved into paraffin blocks and then cut by microtome and stained with hematoxylin-eosin. Brain sections were studied microscopically and photographed.

\section{3- Immunohistochemical assessment:}

Paraffin fixed sections have been deparaffinized and blocking of peroxidase by $30 \%$ hydrogen peroxide in methanol for $10 \mathrm{~min}$ 
then serum blocking solution for $10 \mathrm{~min}$ have been used. Antigen retrieval had been completed by means of emersion of the slides in EDTA solution for $20 \mathrm{~min}$ at $90^{\circ} \mathrm{C}$ in water bathtub.

\section{a) Immunostaining for dopaminergic} neuronal cells (Arias-Carrión et al., 2007):

Brain sections have been incubated at $4^{\circ} \mathrm{C}$ with primary mouse monoclonal anti tyrosine hydroxylase (TH) antibody (diluted 1: 1000) overnight. After numerous washes with PBS, sections had been incubated at room temperature with biotinylated secondary antibody (1: 500) for one hour. The sections had been then incubated with avidin-biotinperoxidase solution for one hour at room temperature. All sections had been washed oftentimes. The response product was modified by incubating the sections with diaminobenzidine. Slides have been counterstained with Meyer's hematoxylin, dried and protected.

b) Immunostaining for LC3 positive cells expression (Mizushima et al., 2010):

Endogenous LC3 was visualized by fluorescent microscope as a diffuse cytoplasmic pool that represents autophagosomes.

\section{c) Computer assisted digital image analysis:}

All analyses were done by blinded researcher who was uninformed of the research proposal. Captured images were analyzed by using Image $\mathrm{J}$ software version ij146-jdk6 for windows 7 (http://download.cnet.com/ Image J-32-bit/3000-21924- 7587 9102.html). The following parts were exposed to image analysis:

i. Image analysis of Striatal Tyrosine hydroxylase (TH) fiber density measurement of dopaminergic neuronal cells:
In order to bilaterally assess the THpositive fiber innervation in the striatum, optical density measurements were done by the use of the Image $J$ analysis software program. To cover the complete striatal complex, from head to tail, snap shots had been taken at seven rostral-caudal levels as reported by Carlsson et al. (2006).

\section{ii. Image analysis of LC3 activation in nigrostriatal pathway:}

Cells positive for LC3 antibodies had been calculated as follows:

Both hemispheres had been counted, in each fourth section, all through the whole nucleus (Blandini et al., 2010).

\section{Statistical analysis:}

Results were studied by the usage of the automated Statistical Package of Social Science (SPSS) software program and excel program for figures analysis. Continuous variables of parametric data have been accessible as mean \pm SD (standard deviation) and for non-parametric data variables have been accessible as median (minimum - maximum). T-test was used to match 2 means while Mann Whitney test was used to match 2 medians. For all the above mentioned statistical assessments carried out, the threshold of significance is fixed at five $\%$ level ( $p$-value).

\section{Results}

Rotenone was found to significantly increase the total distance travelled, numbers of line crossing, average speed, maximum speed and rotations of the animal's body. However, it significantly decreases the efficient path and the total mobile immobile episodes in comparison to control group. 
Table (1): Statistical analysis of neurobehavioral tests (total distance travelled (m) and number of line crossing, the average speed $(\mathrm{m} / \mathrm{s})$, the maximum speed $(\mathrm{m} / \mathrm{s})$, total mobile \& total immobile episodes, path efficiency and rotations of the animal's body) among the studied groups ( $\mathrm{n}=16$ mice).

\begin{tabular}{|l|c|c|c|c|}
\hline \multicolumn{1}{|c|}{ Behavioral tests } & $\begin{array}{c}\text { Control } \\
(\mathbf{n = 8} \text { mice })\end{array}$ & $\begin{array}{c}\text { Rotenone } \\
(\mathbf{n = 8} \text { mice })\end{array}$ & p-value & Test \\
\hline Total distance travelled $(\mathbf{m})$ & $3.42 \pm 0.86$ & $7.86 \pm 2.62$ & $0.001^{*}$ & t-test \\
\hline Number of line crossing & $16.87 \pm 3.27$ & $47.25 \pm 18.7$ & $0.001^{*}$ & t-test \\
\hline The average speed $(\mathbf{m} / \mathbf{s})$ & $\begin{array}{c}0.03 \\
(0.02-0.04)\end{array}$ & $\begin{array}{c}0.075 \\
(0.03-0.09)\end{array}$ & $0.006^{*}$ & Mann Whitney test \\
\hline Maximum speed (m / s) & $\begin{array}{c}0.18 \\
(0.1-0.3)\end{array}$ & $\begin{array}{c}0.33 \\
(0.16-0.86)\end{array}$ & $0.012^{*}$ & Mann Whitney test \\
\hline Total mobile episodes & $8.00 \pm 3.70$ & $4.00 \pm 1.74$ & $0.05^{*}$ & t-test \\
\hline Total immobile episodes & $8.00 \pm 3.07$ & $3.00 \pm 1.82$ & $0.004^{*}$ & t-test \\
\hline Path efficiency & $\begin{array}{c}0.07 \\
(0.01-0.13)\end{array}$ & $\begin{array}{c}0.01 \\
(.00-0.04)\end{array}$ & $0.006^{*}$ & Mann Whitney test \\
\hline Rotations of the animal's body & $\begin{array}{c}4.50 \\
(0.00-7.00)\end{array}$ & $\begin{array}{c}9.00 \\
(7.00-12.00)\end{array}$ & $0.001^{*}$ & Mann Whitney test \\
\hline
\end{tabular}

The data was assessed via t-test (where data is stated as mean \pm standard error of mean) and via Mann Whitney test (if the data is stated as median $\{$ minimum $(\min )$-maximum $(\max )\},{ }^{*}$ significant at $\mathrm{p} \leq 0.05, \mathrm{n}$ : number, m: meter.

The brain sections from the control group stained with hematoxylin and eosin (H\&E) dye show normal architecture with neurons being organized in straight rows with abundant cytoplasm with round and basophilic nuclei (Figure1, Con). In the

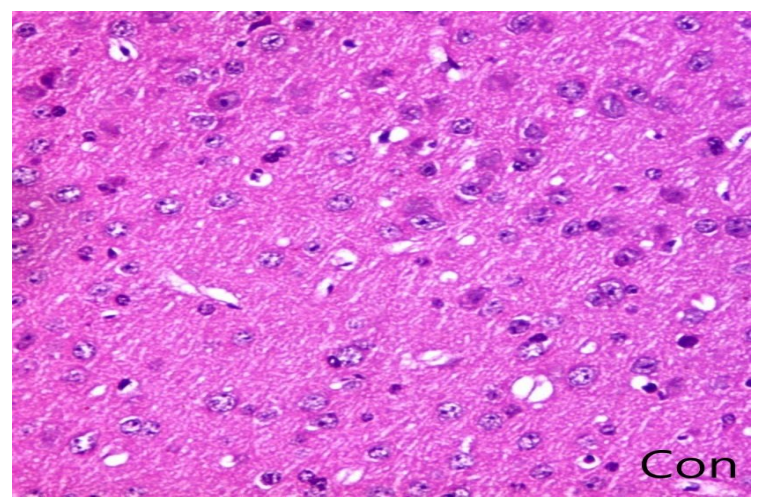

rotenone group, there are extensive degenerative modifications such as shrunken cytoplasm and widely dark pyknotic and apoptotic nuclei in neurons as well as perineuronal vacuolation (Figure 1, Rot).

Fig.(1): A microphotograph sections from the brain of a mouse from the control group (Con) show normal neurons with normal architecture, Rotenone group (Rot) shows severe degenerative changes as numerous extensively dark pyknotic nuclei (arrow) and apoptotic nuclei in neurons (arrowhead), (H\&E X 400).

Immunohistopathological examination of the fiber density of corpus striatum assessed by image analysis shows a statistically high significant decrease in fiber bulk of corpus striatum in rotenone group relative to control group as shown in table (2). 
Table (2): Statistical analysis of the studied groups concerning fiber density of corpus striatum investigated by Image J software ( $\mathrm{n}$ $=16$ mice).

\begin{tabular}{|l|c|}
\hline $\begin{array}{c}\text { Studied groups } \\
(\mathbf{n}=\mathbf{8} \text { mice each) }\end{array}$ & $\begin{array}{c}\text { Fiber density of corpus } \\
\text { striatum } \\
\text { mean } \pm \text { SEM }\end{array}$ \\
\hline Control & $200.25 \pm 2.18$ \\
\hline Rotenone & $83.12 \pm 9.52$ \\
\hline p - value & $<0.001^{*}$ \\
\hline
\end{tabular}

SEM: standard error of mean, $n$ : number.

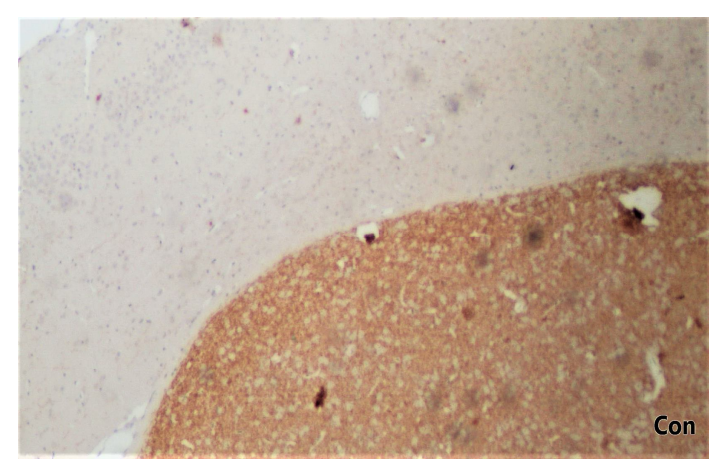

Figure (2) demonstrates the immunestaining for $\mathrm{TH}$ showing the variations in the corpus striatum (CS) of the studied mice. Mice given rotenone (Figure 2, Rot), show significantly more decrease of fiber density in $\mathrm{CS}$ in comparison to the control group (Figure 2, Con).

Fig. (2): Tyrosine hydroxylase immunostaining of corpus striatum in the brain section $\times 10$ magnification. Con: control group, Rot: rotenone group.

Statistical analysis of the number of LC3 positive cells in the substantia nigra pars compacta (SNPC) quantified by Image $\mathrm{J}$ shows significant decrease $(\mathrm{p}=0.009)$ in LC3 positive cells in rotenone group in comparison to the control group (Figure 3).

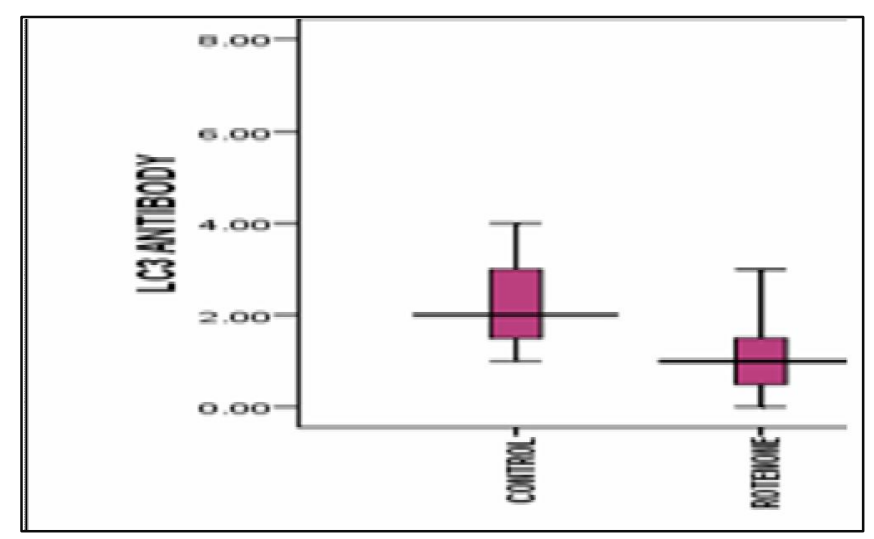

Fig. (3): Box plot for the median values of number of LC3 positive cells for substantia nigra pars compacta (SNPC) quantified by Image J among the studied groups (according to Mann Whitney test) (n $=16$ mice).

Figure (4) shows the immunostaining for LC3 positive cells' expression in the brains of mice in the two groups. Rotenone decreases

significantly the quantity of LC3 positive cells in the brains of exposed mice (Rot) relative to the control group (Con). 

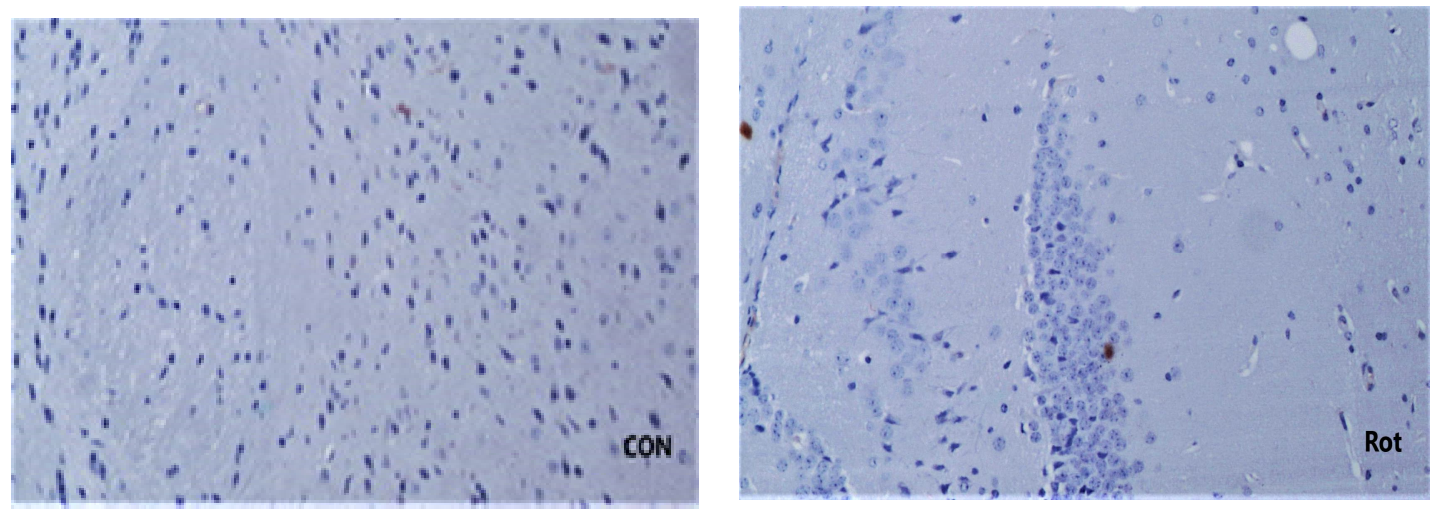

Fig. (4): Microtubule Associated Protein Light Chain 3 (LC3) positive cells expression for SNPC stained with Anti-LC3 antibody in control \& rotenone groups at $\times 10$ magnification, Con: control group, Rot: rotenone group.

\section{Discussion}

In the present study, rotenone precipitated definite locomotor modifications in open field tests. These results were considered together with earlier results described by Swarnkar et al. (2010) and Salama et al. (2013). Histologically, rotenone caused severe neuronal damage that agrees with prior studies stated via Qin et al. (2015) and Abdel-Salam et al. (2018).

In the current study, neurons of the corpus striatum and ventral SNpc region of the midbrain area of mice were examined which are involved in the pathology of some neurodegenerative illness. These dopaminergic neurons are known to be at risk of oxidative stress due to their excessive basal charge of oxygen metabolism, great iron content, combined with a surprisingly excessive basal manufacturing of ROS besides lack of regenerative capability. Added oxidative stress from rotenone- could easily excess the intrinsic anti-oxidative system that ensues in neuronal demise (Hoffman et al., 2019).

In ordinary situations; neurons have great amount of tyrosine hydroxylase, the raterestrictive enzyme liable for catalyzing the change of the amino acid L-tyrosine to dihydroxyphenylalanine (DOPA). Dihydroxy phenylalanine is an originator for dopamine that, in turn, is an originator for other catecholamine (norepinephrine). Tyrosine hydroxylase is found in the cytosol of all cells comprising catecholamines and got decreased due to damage of dopaminergic neurons (Swarnkar et al., 2010).

Present results imply that the mice treated with rotenone shows extensive decrease of fiber density in CS verified with the aid of immunostaining with $\mathrm{TH}$ antibodies. These results augment previous described facts by Inden and his colleagues (2011). They suggested that chronic exposure to rotenone at $30 \mathrm{mg} / \mathrm{kg} /$ day triggered dopaminergic neuron degeneration and motor deficits. Also, it increased the cytoplasmic a synuclein buildup in remaining dopaminergic neurons as well as it affected tyrosine hydroxylase immunoreactivity in the corpus striatum. Moreover, Hoglinger et al. (2005) stated that rotenone induced $23 \%$ reduction of the quantity of $\mathrm{TH}$ positive dopaminergic neurons in the SNpc and $53 \%$ for the corpus striatum in rats. In accordance, Radad et al. (2006) concluded that the expressive neurotoxic effects of rotenone can be due to the discharge of superoxide from activated microglia, increasing ROS creation and inhibiting mitochondrial respiration. 
Autophagy is a critical cell reaction to stress like toxins and oxidative stress. The activation of autophagy might also assist to save cells as a compensatory auto-regulative mechanism. The existing results show that rotenone exposure decreased significantly the quantity of LC3 positive cells inside the brains of exposed mice i.e. neurodegeneration and inhibition of autophagy in dopaminergic system. These finding come in line with previous results of Mader et al. (2012) who concluded that rotenone neurotoxicity has potential influence on autophagy process.

From these results it can be concluded that rotenone inhibited autophagy which may play a role in its neurotoxicity. Further studies are recommended to study the effect of autophagy modulators on neurodegenerative effects of rotenone.

\section{References:}

Abdel-Salam, O.M.E.; Sleem, A.A.; Youness, E.R.; et al. (2018): "Neuroprotection by misoprostol against rotenone-induced neurotoxicity in rat brain". Asian Pacific Journal of Tropical Medicine, 11(1): 40-47.

Arias-Carrión, O.; Freundlieb, N.; Oertel, W.H. and Hoglinger, G.U. (2007): "Adult neurogenesis and Parkinson's disease". CNS \& Neurological Disorders-Drug Targets (Formerly Current Drug Targets-CNS \& Neurological Disorders), 6 (5): 326335.

Blandini, F.; Cova, L.; Armentero, M. T.; et al. (2010): "Transplantation of undifferentiated human mesenchymal stem cells protects against 6hydroxydopamine neurotoxicity in the rat". Cell Transplant, 19: 203217.
Blesa, J.; Phani, S.; Jackson-Lewis, V. and Przedborski, S. (2012): "Classic and new animal models of Parkinson's disease". Journal of Biomedicine and Biotechnology, 2012: 10 pages.

Carlsson, T.; Winkler, C.; Lundblad, M.; et al. (2006): "Graft placement and uneven pattern of reinnervation in the striatum is important for development of graft-induced dyskinesia". Neurobiology of Disease, 21(3): 657668.

Choi, A. M.; Ryter, S. W. and Levine, B. (2013): "Autophagy in human health and disease". New England Journal of Medicine, 368(7): 651-662.

Feng, Y.; He, D.; Yao, Z. and Klionsky, D. J. (2014): "The machinery of macroautophagy". Cell Research, 24(1): 24-41.

Hoffman, M. E.; Augsburger, B. N.; Foradori, C. D.; et al. (2019): "Neuroprotective effects of carnitinoid compounds in rodent cellular and in vivo models of mitochondrial complex I dysfunction". Current Analysis on Biotechnology, 2:26-33.

Hoglinger, G. U.; Lannuzel, A.; Khondiker, M. E.; et al. (2005): "The mitochondrial complex I inhibitor rotenone triggers a cerebral Tauopathy". Journal of Neurochemistry, 95: 930-939.

Hu, W.; Tian, H.; Yue, W.; et al. (2016): "Rotenone induces apoptosis in human lung cancer cells by regulating autophagic flux". International Union of Biochemistry and Molecular Biology, 68(5): 388-393.

Inden, M.; Kitamura, Y.; Abe, M.; et al. (2011): "Parkinsonian rotenone mouse model: reevaluation of longterm administration of rotenone in C57BL/6 mice". Biological and 
Pharmaceutical Bulletin, 34(1): 9296.

Mader, B.J.; Pivtoraiko, V.N.; Flippo, H.M.; et al. (2012): "Rotenone inhibits autophagic flux prior to inducing cell death". ACS Chemical Neuroscience, 3(12): 1063-1072.

Mizushima, N.; Yoshimori, T. and Levine, B. (2010): "Methods in mammalian autophagy research". Cell, 140(3): 313-326.

Netea-Maier, R. T.; Plantinga, T. S.; van de Veerdonk, F. L.; et al. (2016): "Modulation of inflammation by autophagy: consequences for human disease". Autophagy, 12(2): 245-260.

Qin, J.; Wu, M.; Yu, S.; et al. (2015): "Pyrroloquinoline quinone-conferred neuroprotection in rotenone models of Parkinson's disease". Toxicology Letters, 238(3): 70-82.

Radad, K.; Rausch, W. D. and Gille, G. (2006): "Rotenone induces cell death in primary dopaminergic culture by increasing ROS production and inhibiting mitochondrial respiration". Neurochemistry International, 49: 379-386.
Salama, M.; Ellaithy, A.; Helmy, B.; et al. (2012): "Colchicine protects dopaminergic neurons in a rat model of Parkinson's disease". CNS \& Neurological Disorders-Drug Targets (Formerly Current Drug Targets-CNS $\&$ Neurological Disorders), 11(7): 836-843.

Salama, M.; Helmy, B.; El-Gamal, M.; et al. (2013): "Role of 1-thyroxin in counteracting rotenone induced neurotoxicity in rats". Environmental, Toxicology and Pharmacology, 35: 270-277.

Swarnkar, S.; Singh, S.; Mathur, R.; et al. (2010): "A study to correlate rotenone induced biochemical changes and cerebral damage in brain areas with neuromuscular coordination in rats". Toxicology, 272:17-22.

Zheng, S.; Clabough, E. B.; Sarkar, S.; et al. (2010): "Deletion of the huntingtin polyglutamine stretch enhances neuronal autophagy and longevity in mice". PLoS Genetics, 6(2): e1000838. 


\title{
دور الإلتهام الذاتى في السمية العصبية المستحدثة بالروتينون في الفئران
}

\author{
إيمان على عبد الرازقّ، آمال عبد السلام البقرى'، سميرة شعبان حامد'، محمد سلامة ‘، ، \\ أماذى حسز'، سبارة اللدسوقى "، عادل محمود المنصورى'.

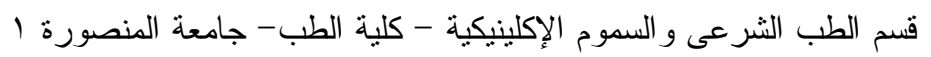

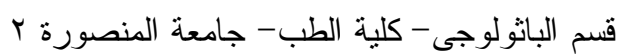 \\ مركز البحوث الطبية التجريبية- كلية الطب- جامعة المنصورة البران
}

يتسبب الروتينون و هو مبيد للأعثاب و الحشرات فى إلتهاب وفقدان خلايا المخ الدوبامينية العصبية. ومن أجل الحفاظ على التوازن السيتوبلازمي يحدث ما يسمى بالإلتهام الذاتي وهو عملية فيسيولوجية يتم خلالها هضم

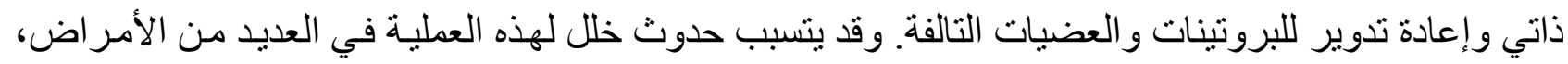
ولقد أجريت هذه الدر اسة لتوضيح دور الاتهام الذاتي فى حدوث الآثار السمية العصبية للروتينون. وقد استخدم فى هذه الدر اسة ستة عشر فأر ا تم تقسيمهم إلى مجمو عتين المجموعة الأولى مجموعة الروتينون (س مجم / كجم

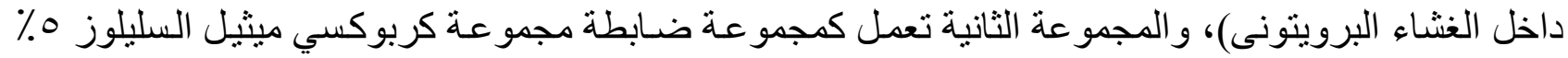

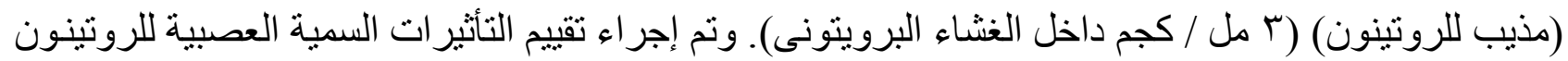

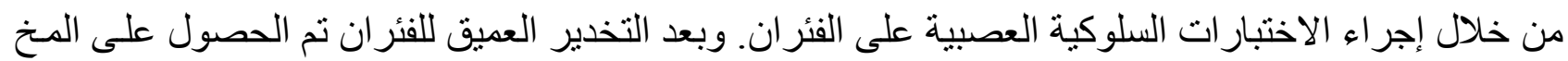
من أجل الفحص النسيجي والمنـاعي الكيميائي. أظهرت نتائج البحث بالنسبة للاختبار ات السلوكية العصبية أن بعدئ

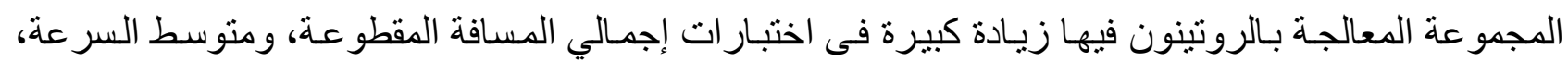

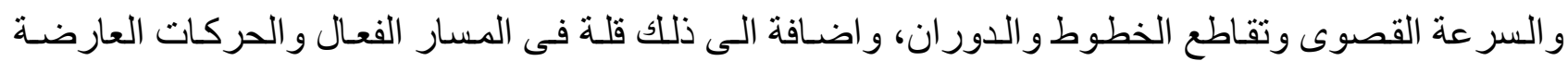
الكاملة و السكون العارض عند مقارنتها بالمجموعة الضابطة. وقد أظهرت نتائج الفحص النسيجي في المجموعة وكة ونة المعالجة بالروتينون تغييرات انتكاسية شديدة. أما التقييم المناعي الكيميائي بصبغة ( protein light chain 3 ( خوجد أن المجمو عة المعالجة بالروتينون قل فيها بشكل كبير عدد خلايا (LC3) antibody خلايـا الدوبامين العصبية الموجودة فى المـادة السوداء بـالمخ (substantia nigra). ومن هذه النتائج، يمكن استنتاج أن الروتينون يحدث السمية العصبية من خلال تثبيط الاتهام الذاتى. 